\title{
小児期における後頭頚椎固定術の治療成績と問題点
}

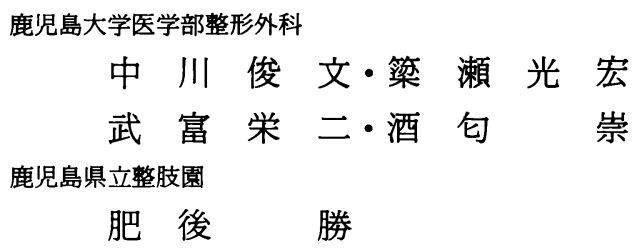

\author{
A Follow up Study of Occipito-cervical Fusion \\ Using A Recto-angular Rod in Children \\ by \\ Toshifumi Nakagawa, Mitsuhiro Yanase, Eiji Taketomi \\ and Takashi Sakou \\ Department of Orthopaedic Surgery, Faculty of Medicine, \\ Kagoshima University, Kagoshima, Japan.

\section{Masaru Higo} \\ Kagoshima Crippled Children's Hospital, Kagoshima, Japan.
}

\begin{abstract}
A follow-up study was done on occipito-cervical fusion using a recto-angular rod in eight children.

Three subjects had congenital dysplasia of the odontoid, three had sustained atlanto-axial dislocation due to Down's syndrome, and two suffered from atlanto-axial rotatory fixation. The mean age of patients at the time of surgery was 8 years 4 months, and mean follow-up period was 5 years 6 months. In all children, symptoms remarkably improved after the operation. Cervical lordosis was slightly progressive, but no problems were seen in activities of daily living.
\end{abstract}

We believe that occipito-cervical fusion using a recto-angular rod is useful even in children.

Key words : children (小児), occipito-cervical fusion (後頭頝椎固定), recto-angular rod (レクタング ラー・ロッド), cervical lordosis (頝椎前弯)

\section{はじめに}

小児の頝椎疾患は比較的稀ではあるが, 上位頝椎部 の先天性奇形, 外傷, 環軸椎回旋位固定などは，小児 に好発し環軸関節固定術が適応されることもある。そ の長期予後の問題点として術後再脱臼，固定部位の成 長障害による前弯増強, 椎体不安定性出現などの非固 定椎間への影響などが挙げられる。当科では, 1985 年以降良好な固定性を得るため, recto-angular rod を用いた後頭顗椎固定術を一部，小児にも応用してい
る. 今回, 術後成績とこれらの問題について検討した ので報告する。

\section{対象および方法}

対象は後頭頝椎固定術後 3 年以上経過した 8 症例て ある. 全例に recto-angular rod を内固定材として用 いた。性別は男児 1 例, 女児 7 例で, 手術時年齢は 3 歳から 12 歳 (平均 8 歳 4 力月), 術後経過観察期間は 3 年 3 力月から 8 年 5 力月 (平均 5 年 6 力月) であっ た。疾患の内訳は, 歯突起形成不全 3 例, ダウン症候 
群に伴う環軸椎亜脱臼 3 例, 環軸椎回旋位固定 2 例で あった，以上の症例を用いて臨床症状の改善, 術後再 脱臼, 頝椎前弯度および頝椎不安定性についてレ線学 的所見を調査した.レ線学的前弯度は西过法に準じ, $\mathrm{C} 2$ 椎体後縁と $\mathrm{C} 7$ 椎体後縁のなす角度より算出した. 不安定性については, white 法に準じ, 上下椎間との rotational angleの差が 11 度を越えるもの, あるい は椎体のすべりが $3.5 \mathrm{~mm}$ を越えるものを不安定性あ りと判定した.

\section{結果}

術前臨床症状として後頭・頝部痛を 7 例に, 手指巧 緻運動障害や歩行障害を 3 例に認めた。最終調査時ほ ぼ全例で症状は消失あるいは著明改善し, 軽度の頝部 痛を 1 例に, 軽度の手指巧緻運動障害を 1 例に認めた だけであった。

レ線所見では, 術後再脱臼をきたした症例はなく, 骨癒合は全例に得られた。最終調査時には, O-C2 固 定の 7 例中 5 例に C3 までの long fusion となってい た. 頝椎前弯は, 術直後 $12.9 \pm 8.8$ 度 (mean $\pm \mathrm{SD}$ ) が最終調査時平均 $23.6 \pm 8.3$ 度となり, 有意に術後䅡 椎前弯増強を認めた. しかし, 臨床的に ADL 障害を 訴えた症例はなかった。また最終調查時レ線にて新た
な頝椎不安性の出現は, rototional angle, すべりの いずれにおいても認めなかった。

$$
\text { 症例 }
$$

症例 $1: 11$ 歳, 女児. 術後に頝椎前弯進行増強を 最も認めた環軸椎回旋位固定例である. 術直後前弯角 9 度が, 最終調査時の術後 6 年 3 カ月で 38 度となり, 後頭骨からC3 まで fusionされた（図 1 )。軽度の回 旋制限を認めるも ADL 障害はない.

症例 $2: 8$ 歳, 男児. 椎間の spontaneous fusion の出現した環軸椎回旋位固定例である。最終調査時の 術後 8 年 5 力月では後頭骨から C3 まで long fusion となり, C2-3 椎間の spontaneous fusionを認めた (図 2 ). ADL 障害の訴えはない.

$$
\text { 考 察 }
$$

1970 年, Roy らは小児期の後頭頝椎固定術では, 術後再脱臼なく, 良好な骨瘺合が獲得されたと報告し た ${ }^{4)}$. 我々の症例でも同様な成績であった。しかし， 後頭頝椎固定術後の頝椎アライメントの変化について は言及していない。一方，Gallie 法あるいは McGraw 法などの環軸椎後方固定の長期成績で:は， 小児の例では swan neck 変形あるいは高度の前弯増
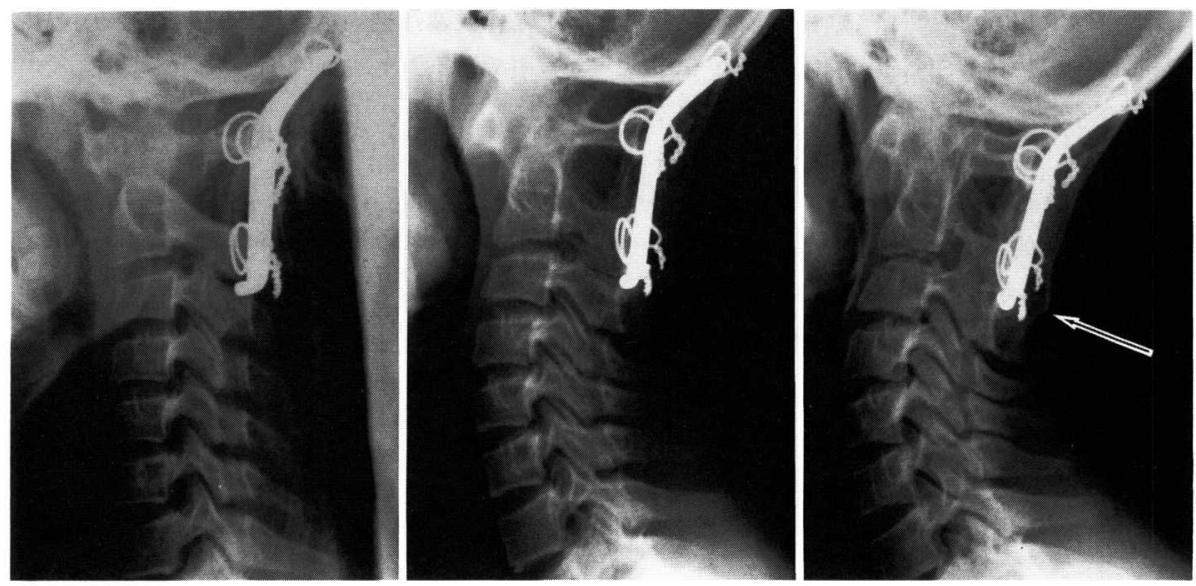

図 1 症例 1.11 歳, 女览. 最大前弯増強進行症例

a) 術後 3 力月単純側面 $X$ 線

b) 術後 1 年 3 力月単純側面 X線

c) 術後 6 年 3 力月単純側面 $X$ 線（最終調查時）

術直後の頚椎前弯角 9 度が, 最終調査時には 38 度と進行した. 最終調查時, 後頭骨からC3 まで fusionされた. 


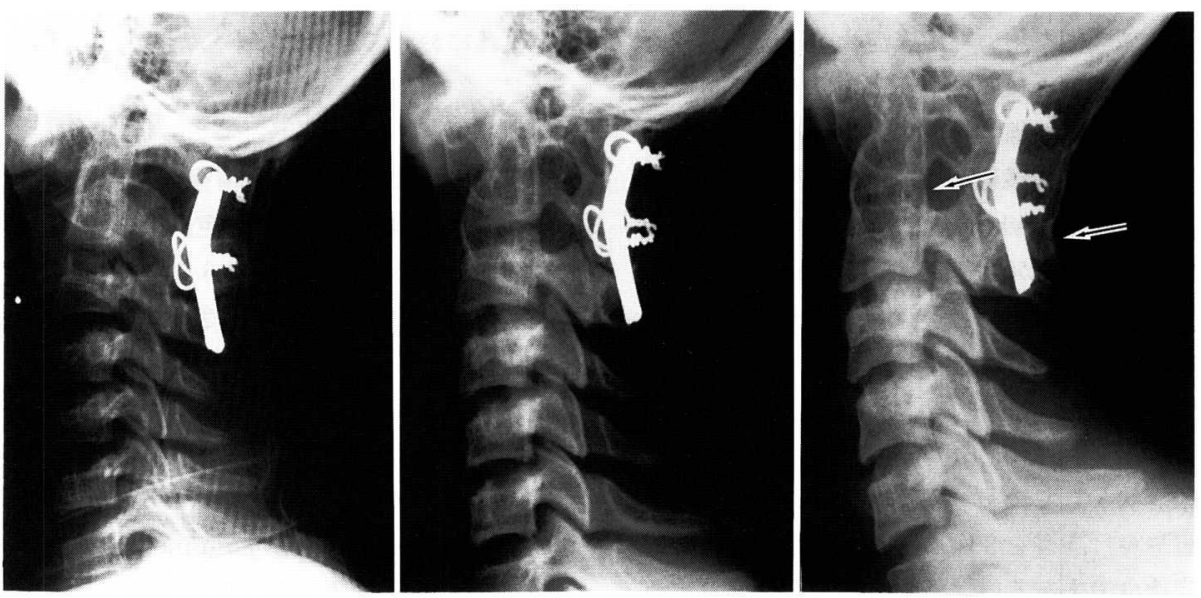

図 2 症例 2.8 歳, 男児. spontaneous fusion 例

a) 術後 2 力月単純側面X線

b) 術後 4 年単純側面 $X$ 線

c) 術後 8 年 6 力月単純側面X線（最終調査時)

最終調査時には後頭骨から C 3 まで fusionされ，C2-3椎間の spontaneous fusionも認めた。

強の出現が指摘されている2)315)．我々の症例では最 終観察時で有意な頝椎前弯増強を認めるも，高度では なく,また swan neck 変形などの新たな頝椎アライ メントの変形の出現も認めなかった.

骨癒合に関して Fielding $ら^{1)}$ は骨瘾合能の旺盛な 小児では隣接椎弓との癒合を生じ long fusion となる 症例が多いと述べた。我々の症例でも 8 例中 6 例で long fusion となり，1例では椎間癒合も生じた。

後頭頝椎固定術は，後頭骨からの long fusion であ り，下位椎間への力学的ストレス增大による不安定性 の出現が危惧された. しかし今回の検討では, レ線上, 新たな不安定性の出現は認めなかった。 今後も注意深 い経過観察が必要と思われる。

\section{ま と め}

1) 小児期に後頭䅡椎固定を施行した 8 例の検討を 行った.

2 ）術前の臨床症状は全例軽快あるいは消失してい
た.

3 ) 術後再脱臼はなく, 良好な骨療合が得られ, 臨 床上問題となる新たな弯曲異常あるいは頝椎不安定性 の出現は認めなかった。

4 ) 後頭頝椎固定術は成長期にある小児においても 有用である。

\section{参 考 文 献}

1) Fielding, J. W. et al. : Spine fusion for atlantoaxial instability, J. Bone and Joint Surg., 58-A : $400-407,1976$.

2) 加藤真介ほか：小児環軸椎後方固定術の成長に及ぼす 影響. 西日本脊椎研究会誌. $12: 97-100.1986$.

3）小林慶二ほか：小児の環軸関節固定術の検討. 臨床整 形外科. $18: 395-402,1983$.

4) Roy, L. et al. : Cervical spine fusion in children, Clin. Ortho., $73: 141-151,1970$.

5）島内 卓ほか：小児の環軸椎脱臼における術後レ線の 検討. 西日本春椎研究会誌. $16: 263-269,1990$. 